\title{
GERMAN-SPANISH BILINGUALISM IN TWO MENNONITE COMMUNITIES IN MEXICO*.
}

\author{
Por \\ Dennis J. Bixler-Márquez**
}

\section{RESUMEN}

El presente estudio se realizó para determinar el grado de estabilidad de bilingüismo (alemán-español) en dos comunidades en Chihuahua, México. La comunidad de la colonia Capulín fue seleccionada porque era representativa de los grupos menonitas más fundamentalistas y conservadores. Un grupo antiguamente menonita en la colonia Swift Current se seleccionó para la contrastación, debido al proceso de aculturación y modernidad que experimentaba. Una encuesta por hogar, entrevistas y prolongadas observaciones, permitieron identificar las características sociolingúísticas dentro de los patrones sociales de las dos comunidades. Unicamente los usos y patrones lingúísticos más obvios revelados en la encuesta son incluidos como reportes preliminares. Se concluye que la comunidad fundamentalista de la colonia Capulín posee un bilingulismo estable, mientras que el otro grupo de la colonia Swift Current más bien se podría definir como de bilingüismo transicional.

\section{ABSTRACT}

This study was conducted to determine the level and degree of stability of bilingualism (German-Spanish) in two German communities in Chihuahua, México. The community of Colonia Capulín was selected because it was representative of the most fundamental and conservative Mennonite groups. A former Mennonite group in Colonia Swift Current was selected to provide a contrast because it was undergoing a significant degree of acculturation and modernization.

* Funding for this study was provided by the Center for Inter-American and Border Studies at the University of Texas at El Paso. The study was authorized and supported by the Secretaría de Educación Pública in Ciudad Juárez, Chihuahua and the Dirección de Educación Pública del Estado de Chihuahua in Nuevo Casas Grandes, Chihuahua.

** An Associate Professor of Elementary and Secondary Studies at the University of Texat at El Paso. He is also Interim Director of the Chicano Studies Program there. His research publication focus on bilingual and multicultural education topics.

Es profesor asociado en el área de estudios de educación primaria y secundaria en la Universidad de Texas en El Paso. Actualmente es director interino del programa de estudios chicanos en esa misma institución. Sus investigaciones se centran en tópicos bilingües y multiculturales. 
A household survey, interviews, and sustained observation yielded the salient sociolinguistic characteristics of selected societal domains in both communities. Only the obvious language use and preference patterns that emerged from the survey were included as preliminary findings. It was concluded that the fundamental community in Colonia Capulín had stable bilingualism, while the group in Colonia Swift Current was best characterized by transitional bilingualism.

\section{INTRODUCTION}

This paper is an overview of a sociolinguistic study conducted to assess the level and the stability of Spanish-German bilingualism in two Mennonite communities in Chihuahua, México. The first community, Colonia Capulín, was selected because it was representative of the most fundamental and conservative Mennonite colonies. A former Mennonite group in Colonia Swift Current was selected to provide a contrast because it was undergoing a significant degree of acculturation and modernization.

The communities were surveyed in 1985 with a 23 -item questionnaire designed to elicit basic demographic data such a the parents' ethnicity and place of birth and the respondent's first language. Each respondent self-rated his proficiency in German and Spanish in speaking, listening, reading, and writing. Then the availability, use, and preference for Spanish and/or German in each respondent's household was ascertained for the societal domains of the church, home, business, education, government, health care, and mass media. Bilingualism was measured across generations in the home domain to determine whether it was stable or transitional. In addition, several community members, church officials, government leaders, educators, and other key people in the surrounding areas were interviewed. To further validate the questionnaire findings, this writer also observed and documented sociolinguistic behavior in settings such a classrooms, stores and medical facilities. Data from interviews and observations, as preliminary findings, appear in this article as well as some of the language use and preference patterns that emerged during the administration of the questionnaires.

\section{THE MENNONITES}

The Mennonites derive their name from Menno Simons, an ex-Catholic priest and contemporary of Martin Luther, who broke from the Roman Catholic Church and became the leader of a pacifist branch of the Anabaptists in the low countries (Smith, 1950). Mennonites have long suffered religious persecution, wich has prompted them to emigrate to various countries. Conversely, they have been sought as settlers because of their agrarian expertise and strong work ethic. A large group of Mennonites spent over two centuries in Prusia, then left for Russia in 1789 nt the invitation of Catherine the II. Other groups of Mennonites followed their lead 
and seuled in Russia in the 19th century. The inhabitants of the first wave established a colony at Chortitz and became known as the Old Colony Mennonites or "Altkolonier Reinlaender Mennoniten Gemeinde" (Redekop, 1966). The removal of the exemption from military service and other goverment-initiated modifications to the agreement governing the presence of Mennonites led to an exodus from Chortitz between 1874 and 1880 (Fretz, 1945).

The history of Mennonites is punctuated by fragmentation prompted by differing interpretations of the tenets of the Mennonite faith (Friesen, 1983). Post1850 schisms in Mennonite groups often have been marked by changes in language use, such as the shift from German to English in Canada and the United States by some groups; the adoption of such religious institutional practices as Sunday School and evangelistic services; and other signs of acculturation. Because carly Mennonites were persecuted for their beliefs, wich included pacifism, refusal to take an oath of allegiance to a government, individualism in faith, and isolation, they withdrew from the surrounding society to create a life style marked by nonconformity to social practices in the larger milieu (Friesen, 1985 \& Wenger, 1977). This isolationism became a central part of the religion, often resulting in strong cultural cohesion but also, in some cases, causing schisms (Dick, 1981).

Canada was one of the areas where some of the Mennonites chose to relocate from Russia. In Canada's western provinces the Mennonites prospered and helped the colonization efforts of the government, but govemment encroachment in their communities and differences among themselves resulted in yet another migration. From 1922-1927 approximately 10,000 Mennonites from the Old Colony and Sommerfelder Mennonites, the most conservative of Mennonites (Wenger, 1959), left Manitoba and Saskatchewan in search of a new home in Mexico. They left in protest of the secularization of the schools in Canada, where English was mandated as a medium of instruction, and attempts to force their young men to serve in the armed forces during World War I (Schmiedhaus 1973).

In México the Mennonites initially settled around the city of Cuauhtémoc, located approximately 50 miles east of Chihuahua City, the capital of the state of Chihuahua, and in Patos, Durango, a community situated south of Chihuahua. (Please see Figure 1).

\section{CAPULIN AND SWIFT CURRENT COLONIES}

The communities in the Capulin and Swift Current colonies were selected for this study because they varied significantly in their level of adherence to the fundamental precepts of the Mennonite religion. This permitted an analysis of the wide range of factors that led to cultural maintenance and economic survival in one case and cultural and economic adaptation in the other. In 1985 Colonia Capulfn was an example of planned cultural encapsulation, whereas the group of former 


\section{Dennis J. Bixler-Márquez}

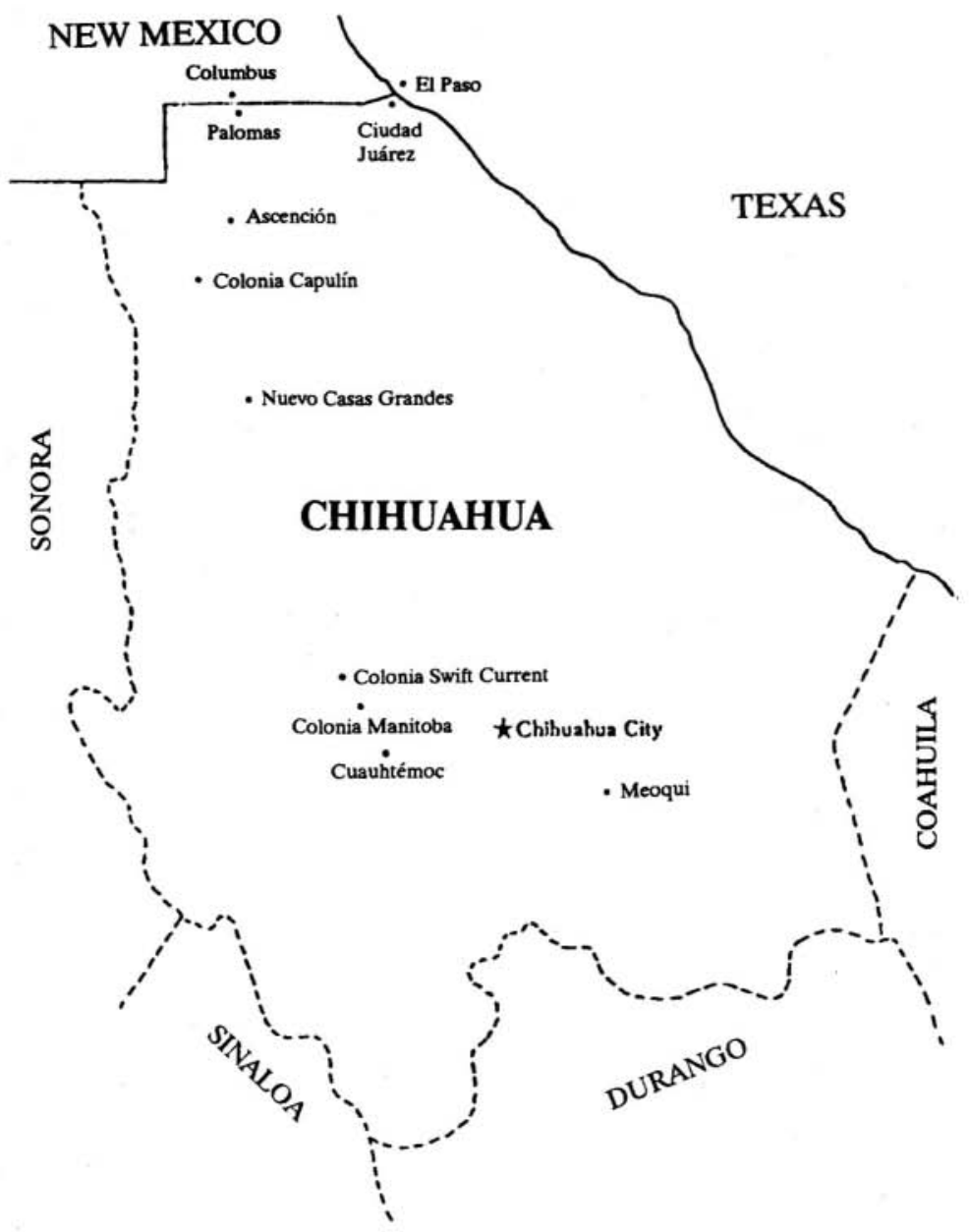

FIGURE 1. 
Mennonites studied in Colonia Swift Current was undergoing acculturation and limited modernization in order to adapt to prevailing economic conditions (Biwler Márquez, 1989).

\section{THE GERMAN CHURCH OF GOD CONGREGATION IN COLONIA SWIFT CURRENT}

In 1985 Colonia Swift Current consisted of 17 units commonly referred to as camps. It was established approximately 25 miles north of the city of Cuauhtémoc, close to the border with Colonia Manitoba (see Figure 1). Camp 101 in Colonia Swift Current housed the church, school and homes of the minister and teacher of a congregation of former Mennonites. It should be noted that the majority of the inhabitants in Camp 101 did not belong to the aforementioned congregation, the group contrasted with Colonia Capulín.

There were approximately 45 families in the former Mennonite population under study in Colonia Swift Current in 1985. They gradually became a congregation in order to promote a more modern and progressive life style than that of fundamental Old Colony Mennonites in the region. Their occupational status changed over the years from farming to farming coupled with agricultural industries and services. In 1988 some of the members of the community were engaged in the manufacture of farm implements and machinery, as well as in servicing tractors, trucks, and other agricultural implements. The level and type of economic activities that these former Mennonites performed required that they be able to interact affectively with Mexican society. At the same time, the group also desired to retain a distinct, if nonfundamental, cultural identity.

A preliminary analysis of the life style of the group in Colonia Swift Current clearly indicated that it was relatively modem and distinct from that of fundamental Mennonite groups, such as the one in Colonia Capulín. The men dressed in Westerns attire like other middle-class Mexican males in the region; however, older males still wore the traditional denim overalls. The women generally retained the traditional Mennonite dress style, simple but colorful dresses and scarves and/ or hats for outdoors.

The church building on the road to Cuauhtémoc was an imposing structure that stood out from the surrounding rural environment. Similarly, the school that was adjacent to the church was a modern edifice equipped with a lunchroom. The facility compared most favorably with the best of federal and state schools in the rural areas of Chihuahua. Houses of this community, wich were dispersed over a region that included two major Mennonite colonies and a small town, ranged in architectural style from adobe dwellings to modern brick structures. More recently built homes had a contemporary design and were equipped with modern major appliances, a break with the conservative Mennonite tradition that eschews 
acculturation, especially in the form of mechanical conveniences. Most of these homes were sparsely furnished, but others had modern conveniences that included refrigerators, toaster, etc. Television and radios were still not allowed in their homes, though some members of this group were exposed to broadcasts when they visited their relatives in Canada.

The men drove automobiles and trucks that had radios in them and used farm equipment such as tractors with rubber tires. They also emplyed motorized farm machinery and other modern implements normally not found in a fundamental community. The males, often accompanied by their families, frequently traveled to urban areas. In the more conservative communities like Capulín, this type of interaction with the outside world was kept to a minimum.

All these features of modemization and acculturation -modern appliances and vehicles- led to a reformulation of the group's cultural identity, no longer in the traditional mold of the Mennonite religion, marginal to the surrounding society, but certainly very far from being assimilated into the national culture of Mexico. These former Mennonites were in 1988 at a critical stage of acculturation -one they believed they could direct and, more importantly, constrain.

The first step toward acculturation taken by these former Mennonites was to reconstitute themselves on a religious basis in 1975; they became members of the German Church of God (Gemeinde Gottes). The school's headmaster explained that the group belicved that naming a religion after a man was wrong; therefore, they no longer called themselves Mennonites (Thiessen, 1984). They aligned themselves with a protestant religion based in Canada that other comparably modern Mennonites had joined because many of their practices still adhered to the old ways. However, by no longer calling themselves Mennonites, they created enough distance from that identity that they made their precepts and customs more consonant with their socioeconomic needs and preferred life styles. They remained ethnic Mennonites by tradition, not by religion. There were Mennonites churches in the region that were just as modern, but this group did not choose to be affiliated with them.

The basic differences in lifestyle with other fundamental Mennonites in the area and those of Colonia Capulín were reflected across societal domains.

\section{COLONIA CAPULIN}

In the Colonia Swift Current group, acculturation was marked, at least in contrast to the one in Colonia Capulín, wich was relatively isolated -accesible only via a dirt road that branches off from Federal Highway 2 . Ten camps in this colony accommodated approximately 250 families (an average of 25 families per camp). The inhabitants of camp number four ( 40 families), those surveyed for this 
research, were overwhelmingly engaged in farming. Even the two owners of the small community store and the teacher had their own farms. They grew sorghum alfalfa, some wheat, and other crops. Their dairy products, such as cheese, were well known throughout México for their quality.

The Mennonites of Colonia Capulín did not drive motor vehicles, though they rode in them. They used horse-drawn buggies or wagons for transportation within the colony. Rubber tires were removed from tractors and other farm machinery to insure they were used as tools of work and not as a form of transportation.

The church and school buildings in Colonia Capulín, in contrast with the relatively ostentatious church and modern school building in Colonia Swift Current, were modestly constructed and furnished. Many of the structures were adobe, including the school and the church. More modern materials, such as brick and corrugated steel roofs, also were seen in some of the homes and barns.

Dwellings were fusnished in an austere manner. Most of the furniture was homemade in plain styles learned from their ancestors in Holland, Prussia, Russia, and Canada (Redekop, 1966). They heated their homes with wood or kerosene stoves. Few modern appliances were in evidence, mostly gas-powered refrigerators and water heaters. No electrical devices could be used because the community, by its own accord, did not receive electricity from the government.

Both men and women dressed in traditional Mennonite style. The men always wore denim overalls (belts were considered worldly goods), simple shirts, and straw hats. The women only wore typical Mennonite attire in colors that appeared more subdued than those found in the clothing of the more acculturated Mennonites in the Cuauhtémoc region.

\section{THE HOME DOMAIN IN COLONIA CAPULIN}

The Mennonites of Colonia Capulín spoke German (Low German or "PlattDeutsch") exclusively at home. Interactions between parents and children, parents and their parents, and children and their grandparents were conducted in German Spanish was used by males when they came in contact with Mexican field hands and buyers of their products. This pattern of interaction in and around the home resulted in males being almost exclusively the ones to become bilingual. Females, who were generally restricted from interacting with non-Mennonites, remained, by and large, German monolingual. Sawatsky (1971) viewed the monolingualism imposed on Mennonite females as a protective measure against the deterioration of the family structure through contact with the host society.

\section{THE HOME DOMAIN IN COLONIA SWIFT CURRENT}

The members of the German Church of God indicated they allowed and even encouraged the use of Spanish by their children, though most interaction were in 
German (Low German). Parents and their children used German almost exclusively with their parents and grandparents, respectively. Spanish was used sparsely by children among themselves and with their parents. Spanish was used more at home in this colony than in Colonia Capulín, though not in substantial amounts in 1985.

Since the shift to a new religion and educational program was recent, interactions at home were not yet affected by the increased presence for Spanish among the young in other societal domains.

\section{THE EDUCATION DOMAIN IN COLONIA CAPULIN}

Schooling for the 42 children in Colonia Capulín's Camp \#4 was conducted totally in German. Bidialectalism existed in the classroom because some of the printed matter in the curriculum was in High German, while the teacher taught mostly in Low German. The teacher informed this writer that some teachers in the nearby camps encouraged parents to use High German at home to support the school's language practices but, he stressed, that was not the case in Camp \#4.

The interviewed parents unanimously preferred a German monolingual program over other language education programs such as bilingual education. They also acknowledged their male children would inevitably acquire Spanish in the fields -far more than they would like.

Schooling was restricted to the elementary grades (1-6) and was available to boys and girls, who were segregated inside the one-room schoolhouse. The sevenmonth school year (usually September to March) was adjusted to accommodate the planting and harvesting of the crops.

The school was sparsely furnished: a teacher's desk, old fashioned study desks, a blackboard, and a kerosene stove. The building had an adjacent, interconnecting room where the teacher had the option to reside.

The curriculum adhered to the community's customs, norms, and sociocultural expectations. The education of the Mennonites was designed to enable them to function in their own agrarian society and to conduct business with the outside world in a limited manner. Thus, the acquisition of basic literacy skills and computational abilities related to ranching, agriculture, and the marketing of their respective products were emphasized. Lastly, religion was a subject that permeated the entire curriculum, with biblical examples used prolifically. The teacher was monitored by community members to insure that the education was not conducive to assimilation or in violation of the fundamental tenets of the Mennonite faith, as interpreted by the community (Schimidt, 1985).

All five textbooks for the six grades were in High German and had a religious content. These were a primer, a first reader, the Bible according to Martin Luther, 
and a set of religious hymn books. The teacher also employed some mathematic workbooks that covered fractions, percentage problems, stated problems appropni: ate to an agricultural economy, and lists of measurement equivalents. In addition, tracing cards with gothic print and longhand were used by students to develop theif penmanship. The latter facilitated the mastery of the complex gothic writing.

A Mennonite bookstore and press located on the 6-1/2 kilometer marking on the road from Cuauhtémoc to Colonia Swift Current was the school's main supplie of instructional materials. Some of these materials were imported by the store from Germany, Canada, and the United States. For example, a hymn book used in Colonia Capulín was printed in Scottdale, Pennsylvania.

Learning in this Mennonite school took place mostly by rote. The teacher led the students in repeated oral recitation, e. g., everyone chanted "one meter has one hundred centimeters, one meter has ten decimeters", etc. Since all six grades were housed in the one-room school, the teacher; even in rote teaching, employed cross age tutoring; the older students had the responsability of helping the younger onew. Religious hymns, which the average Mennonite student mastered in excess of 730 , were sung daily, interspersed throughout the $8: 30$ to 3:30 school day, which included a noon lunch period and recesses during the moming and afternoon.

The teacher, always a male, was paid by the community from its own local taxsupported treasury. His education was typically the same as the highest grado reached in his own school, sixth grade. He met periodically with the teachers from the other three Mennonite schools in the nearby camps to exchange information about methodology, curriculum, and other school concerns. During the summer he tended to his own land and economic interests; his family had a small dairy that also produced cheese.

\section{THE EDUCATION DOMAIN IN COLONIA SWIFT CURRENT}

The Escuela Particular 101, "La Esperanza", was the elementary school of the German Church of God congregation in Colonia Swift Current. The school was founded in 1976 and served approximately 82 students of both sexes in grades 1 6. The first class of students graduated in 1980; some of these students started their education in nearby traditional Mennonite schools.

The education of the children in this community reflected the more progressive stance of its members. The elementary school was accredited by the Secretaría de Educación Pública (the federal department of education), because it offered a bilingual curriculum that complied with Mexican cultural and academic requirements set forth by the said agency. 
Those parents who desired that their children continue their education beyond the 6th grade sent them to a federally accredited high school in Quinta Lupita, a nearby community in Colonia Manitoba that served another Mennonite colony that also departed from the conservative church of the Old Colony Mennonites and, apparently, influenced the German Church of God group in Colonia Swift Current. In 1988 an independent study high school program was authorized by the federal department of education; a few students pursued secondary studies under the guidance of a certified teacher who periodically provided them with assistance and oficially monitored their progress.

The elementary school was located on the road to Cuauhtémoc next to the church building previously mentioned. The building had four classrooms and a lunchroom that were as well equipped as the average urban elementary school in México. The school had two vans to transport the students who did not reside within walking distance. The school was financed by the community's contributions for education and by income derived from orchards adjacent to the church, wich were part of the school's endowment.

The curriculum was presented in German and Spanish, with far less reliance on the rote teaching methods employed in Colonia Capulín. Spanish was gradually added to German, which was used exclusively as a medium of instruction in first grade. The proportion of German to Spanish was 70/30 in second grade, 60/40 in third grade, and 50/50 in fourth grade. By the fifth and sixth grades the proportion was $75 / 25$ Spanish to German. Until 1986, English as a third language was taught two hours a week in the upper grades by a teacher who had recently returned from Canada. The English component, explained the principal in 1987, was set aside in order to better promote the mastery of Spanish. Statistics on academic achievement in Spanish and Spanish-taught subjects for this school did not compare favorably with those of a nearby school with all-Spanish curriculum in 1986.

Religion played an important role but did not permeate the entire curriculum as it did in the school of Colonia Capulín. The textbooks in Spanish were provided by the federal government, with some materials purchased from comercial sources. Textbooks in German were purchased from a Mennonite book store near Cuauhtémoc, ordered from Germany, and some were obtained from an elementary school at Fort Bliss (in El Paso, Texas) that was operated by the German Air Force for its personnal.

All the heads of households interviewed preferred a maintenance bilingual education program over any other languagee education program, including a German monolingual one, and in 1985 they were happy that English was added to the curriculum. It was their perception that more avenues of employment would be available to their children if they learned the national language in addition to their own. Furthermore, their commercial contacts with the United States and personal relations witch Canada made the acquisition of English desirable. 
The principal of the school and minister of the church in 1988 was assisted by three female teachers, who averaged 18 years of age when they first began teaching in 1984. The principal was the unofficial head of the school because of this personal level of educational attainment, which, like that of his counterpart in Colonin Capulín, was a sixth-grade education. The federal government recognized one of the three female teachers, completed a secondary education in a state-operated high school in the nearby town of Rubio. In addition, the three female teachers were on the waiting list for a summer federal teacher certification program in Durango, Durango. The government periodically operated teacher training institutes for teachers who did not have a teaching certificate and who were committed to remaining in rural areas. The principal also was taking courses to improve his academic and professional standing. He and the three teachers were the vanguard of the congregation's effort to increase the educational level of its members. Eventually the German Church of God may add a high school to their present educational program, though not all members of the church would like for their children to attain such a level of education. Some feared that their young may change beyond their established social limits, as did some of those Mennonites who resided closer to Cuauhtémoc.

\section{THE MASS MEDIA IN COLONIA CAPULIN}

Electronic mass media was virtually nonexistent in Colonia Capulín. By choice there was no electricity in the community so there were no electrical appliances, radios, televisions, telephones, record players, etc. These were forbidden by the religion, but the parents recognized that the young were attracted by the music that they heard from radios in vehicles driven by Mexicans who conducted business in the area. Adolescent Mennonites also were exposed to music in their trips -some unauthorized- to Nuevo Casas Grandes, Chihuahua. While visiting homes, this writer noticed that when children came out to greet him, they often wanted to turn on the car's radio.

Some households had German-language newspapers that were published in Canada and Cuauhtémoc and could be purchased in the community store. These periodicals had sections on news from Canada, México, and South America. Some heads of households indicated they did not care to read these publications. Most households had religious publications, such as the Bible, hymn books, and Mennonite history books.

\section{THE MASS MEDIA IN COLONIA SWIFT CURRENT}

The Mennonites of Church of God, like the Mennonites of Capulin, forbade the use of television and radio. This community had electricity in many of the homes, where appliances such as radios were found. There were radio stations in Cuauhtemoc that broadeasted German language commercials, brief news pro- 
ntams, and religious music programs. This writer noticed radios in some of the trucks and cars parked at homes that he visited. Some of their owners, however, had vategorically stated they did not listen to the radio.

The availability of radio was primarily in Spanish in the area, while publications in German were available from Canada, the United States and México. Most members of the visited households read publications in German. A few adolescents indicated they viewed television during visits to Canada, where their relatives did not prohibit their use. Evidently, the community was gradually increasing their use of electronic media, though its use remained very controversial.

Printed media was more available and used in Colonia Swift Current than in Capulín. The Colony's proximity to the Mennonite presses and bookstores may have accounted partially for this difference between the two colonies. The young people being educated appeared to have led in the quest for knowledge, which they recognized was available in media heretofore inaccessible to them. Heads of households who used printed or electronic media expressed a preference for media in both German and Spanish, if it were equally available.

\section{THE BUSINESS DOMAIN IN COLONIA CAPULIN}

All local purchases were made in German at a centrally located, Mennoniteowned store. This store served as a place where news and information were exchanged and newspaper bought and where a traveler could hitch a ride to the highway to board a bus. The owners of the store had a native proficiency of Spanish, undoubtedly acquired as a result of frequent interaction with Mexican nationals who visited their store to purchase milk, cheese, etc. and their interaction with suppliers in Nuevo Casas Grandes and Ciudad Juárez, Chihuahua.

Several purchases were made in Nuevo Casas Grandes by individuals. This, of course, necessitated some minimal proficiency on Spanish. In addition, individuals at times had to conduct business with a bank or major buyer. If a Mennonite did not feel comfortable conducting business in Spanish, a friend, relative, or the leader of his camp translated for him.

Mennonites as individuals or as families traveled to the United States to make major purchases, e.g., farm equipment, parts, and other items that will be discussed later. In El Paso, Texas, it was possible in 1989 to make almost any purchase in Spanish, so English, however convenient, was not essential. Some of the spare parts such as well retainers, tractors tillers, etc. were manufactured and sold by Mennonites who resided close to Cuauhtémoc, but some less expensive or special parts were acquired in the United States.

The majority of male Mennonites in Colonia Capulín were bilingual with enough proficiency in Spanish to conduct business effectively in México. They 
hired attomeys or public notaries for more complicated transactions, such an the purchase of land. The Menronites had no desire to acquire any more Spanish than neccesary for economic survival. Consequently, the level of literacy in Spanish in the community was minimal because most business in Spanish was conducteal orally, with professional assistance obtained for documented transactions.

\section{THE BUSINESS DOMAIN IN COLONIA SWIFT CURRENT}

Most small purchases in Colonia Swift Current were made in the stores located on the main highway to Cuauhtémoc and in nearby Rubio, the closest town servic ' stations, super markets, and stores. Medium and large purchases were made in Cuauhtémoc, Chihuahua City, and the Ciudad Juárez-El Paso metroplex.

The Mennonites in the Cuauhtémoc region were self-sufficient in many arcus. They excelled in the field of agricultural goods and also were engaged in the manu facture of industrial products for export outside their communities. Between Colonia Swift Current and Cuauhtémoc there were several Mennonite enterprises: dairies, cheese factories/retail outlets, satellite antenna manufacturing, farm machinery shops, print shops, hardware stores, and truck/tractor service industries. Commercial interaction with the Mexican population extended the linguistic parameters of the colonies. The operators of Mennonite enterprises usually had ॥ very good command of Spanish and were cognizant of the economic advantage of being bilingual.

Some of the Old Colony Mennonites who remained in Canada, because they wanted to add English to the German curriculum, were also engaged in commercial and industrial enterprises. Their economic future depended on their ability to communicate effectively with the larger English-speaking community and, therefore, they opted to stay in Canada rather than to emigrate to México. They specifically opted for English instruction in their schools. This group became affiliated with a different branch of the Mennonite Church. This economically motivated change of religious affiliation also was discernible in ColoniaS wift Current region.

The owners of the only store on Colonia Capulín, two brothers, double as a dentist and physician. Their medical expertise was obtained from German medical books and on-the-job training. Medical supplies were often purchased in the El Paso-Ciudad Juárez metroplex. These self-trained "physicians" handled most medical emergencies and routine services, which were rendered in German. At times, community members received medical care from a doctor who came from the Mormon community of Colonia Juárez.

Some Mennonites sought medical attention in the United States or from other folk healers in Mennonite communities in the state. This writer took one of the community leaders and some of his children to visit a Mennonite folk healer in 
Mennonite colony west of Cuauhtémoc. A significant amount of medical services were obtained in Spanish in México and the United States, where some communicated with English monolingual physicians through bilingual (Spanish-English) nurses. Several physicians in El Paso were Spanish-English, which eliminated the need for translation, though some translation was often necessary because the patient was a German monolingual child or spouse who relied on a GermanSpanish bilingual adult for translation services.

The respondents indicated that local medical services were obtained mostly in German. They would prefer that the more specialized health services were also available in German in nearby urban areas, but they realized that was not a realistic alternative.

\section{THE MEDICAL SERVICES DOMAIN IN COLONIA SWIFT CURRENT}

The relative proximity of this colony to Cuauhtémoc, a city of about 80,000 inhabitants, facilitated the use of urban health care by these relatively mobile Mennonites; most adult males owned motor vehicles. They obtained health care in Cuauhtémoc mostly in Spanish. They were also local Mennonite healers and physicians who served this community in the German language. The more affluent Mennonites in need of specialized care obtained it in the United States or in Chihuahua City, wich is less than two hours away by car from Colonia Swift Current. Thus, German and Spanish were used to obtain most local and regional medical services, but far more Spanish was used for medical services in this community than in Colonia Capulín. The use of English in this domain was as reduced as that of the residents of Colonia Capulín. The Mennonites in Colonia Swift Current also would like to have more medical service available in German if it were possible, especially the older generation.

\section{THE RELIGION DOMAIN IN COLONIAS CAPULIN AND SWIFT CURRENT}

The church service on Sunday and special occasions like Christmas were conducted totally in German in both colonies. This domain constituted the principal safeguard for their native tongue. There were some dialectal differences between the two groups that were of interest. The former German Church of God Minister in Colonia Swift Current, who came from Germany via Canada, addressed his congregation in High German. Several of the religious books found in the homes of Colonia Swift Current community were printed in what this writer's sources labeled "archaic" German. In contrast, in Colonia Capulin the preacher used a combination of High and Low German when conducting services to facilitate communication with the congregation. All respondents in both colonies received and preferred religious services exclusively in German, which was the only language in which they were available. 


\section{THE GOVERNMENT DOMAIN IN COLONIA CAPULIN}

In Colonia Capulín all government transactions, such as paying taxes, were handled in German by the community leaders, who in turn officially interacted in Spanish with government agencies at the regional, state, and federal levels. The leaders sometimes obtained assistance from professionals when more complex issues arose, such as establishing the right to be exempted from military service. This community generally did not express a desire to have government service in Spanish, though some members who dealt with the bureaucracy would appreciate it.

\section{THE GOVERNMENT DOMAIN IN COLONIA SWIFT CURRENT}

The Mennonites of the German Church of God in Colonia Swift Current, by virtue of residing in various camps in two colonies, tended to handle more government business on an individual basis. Their socioeconomic mobility dictated that they individually be able to use Spanish in obtaining driver licenses, vehicle registration permits, passports, etc. Their progressive stance probably accounted for their lack of desire for goverment service in German; they were criticized at times by bureaucrats when they were unable to express themselves effectively in Spanish. They were cognizant that request for service in German could generate ill will against them as a group.

\section{CONCLUSIONS}

Colonia Capulín had stable bilingualism due to a strict assignation of German and Spanish to different functions by societal domain. The community was relatively insulated from the outside world by design. The German language had primacy due to its protected status in institutions such as the church, home, and school. While the medical domain favored both languages, other powerful institutions like the mass media were effectively prevented from influencing the community's linguistic and cultural patrimony. Interactions by community members in the government and business domains were semi-controlled; only some pre-selected members operated in those domains. Family participation in shopping and business trips was also restricted through adult male supervision. To the extent this community can maintain its geographic, linguistic, and sociocultural isolation, it probably will maintain the present level and stability of bilingualism, which was designed to promote a very high level of linguistic and cultural autonomy. No change was foreseen in 1988 that could alter the stability of the current structure of bilingualism in Colonia Capulín.

Colonia Swift Current's bilingualism was transitional. This community deliberately and systematically began a shift toward Spanish by increasing its use in the key societal domains of eduaction, business, government, and, to an unwilling and limited extent, the mass media. The church and the home remained bastions of 


\section{Dennis J. Bixler-Márquez}

lierman, but the medical services domain supported both languages and, even a lhird, English, wich at one time was officially supported in the educational system. This separation of social functions for Spanish and German will contribute to the utubilization of bilingualism in the future. However, the linguistic and cultural domands of the business domain, coupled with the forces of assimilation and modernization, may result in a continued shift from German to Spanish beyond the parameters originally envisioned in 1976.

\section{REFERENCES}

BIXLER-Marques, D. J. , 1989. "The migratory patterns of two Mennonitee communities in México". Journal of Borderland Studies, III(2).

DICK, J. C., 1981. An introduction to Mennonite history. Scottdale, Penn: Herald Press.

FRETZ, W. J., 1945. Mennonite colonization in México, an introduction. Akron, Penn.: The Mennonite Central Commitee.

FRIESEN, J. W., 1983. Schools with a purpose. Calgary, Alberta: Detselig Enterprises Limited.

1985. When cultures clash: Case studies in multiculturalism. Calgary, Alberta: Detselig Enterprises Limited.

REDEKOP, C., 1966. "The Old Colony: Analysis of group survival". The Mennonite Quarterly Review, 1966.

SAWATSKY, H. L., 1971. They sought a country. Berkeley, Calif.: University of California Press.

SCHMIDT, J. 1985. Personal interview with the Mennonite teacher of Camp \#4 in Colonia Capulín, Chihuahua, México (January 7).

SCHMIEDHAUS, W. 1973. Los Mennonitas. Cuauhtémoc, Chihuahua, México: (no press listed).

SMITH, H.C. 1950. The story of Mennonites. Newton, Kansas: Mennonite Publication Office.

THIESSEN G. 1984. Personal interview with the principal of the German Church of God congregation's school in Colonia Swift Current, Chihuahua, México (May 12).

WENGER, J.C. 1959. Glimpses of Mennonite history and doctrine. Scottdale, Penn: Herald Press.

1977. What Mennonites believe. Scottdale. Penn: Herald Press.

ZEC, J. 1986. The Mennonites in Chihuahua (video). KVIA, El Paso, Texas, (july 29). 